\title{
Development of Activity Model Students of State University of Medan
}

\author{
Sahat Siagian \\ Educational Technology, Postgraduate, Medan State University \\ Pardomuan Sinambela \\ Faculty of Mathematics and Natural Sciences, State University of Medan \\ Andre Hutapea \\ Faculty of Mathematics and Natural Sciences, State University of Medan
}

\begin{abstract}
The problem in this research is the need to increase student creativity. Morevoer, it is also necessary to arrange and design what activities students need and must do to produce students who have good creativity. Student activities are spread out in several fields including interests and talents, welfare, reasoning and science. The State University of Medan is a tertiary institution where the pattern of teaching and coaching students is based on the creativity of the students. Therefore, the researchers are interested in developing student activity models that can increase student creativity. This study aims to develop a model of student activities to increase student creativity at the State University of Medan. This research is a Developmental Research. The product of this research is the formation of an activity model that can increase the creativity of students. The method used in this research was descriptive method. This research was conducted in three major stages. A series of detailed activities that must be carried out in this research included research and information gathering, planning, development of initial product forms, initial field trials, major product revisions, main field tests, operational product revisions, operational field tests, final products. revision, and dissemination and implementation. The final stage of this research is to disseminate the results of the second year of research if it is found that the designed activity model is effectively applied to increase student creativity. The results of this research will be published in a well-reputated journal and presented at an international seminar. In addition, research products which will be produced is the SOP for each activity in the field of student affairs.
\end{abstract}

Keywords: Development, Student Activity Model

DOI: $10.7176 / \mathrm{IKM} / 11-1-02$

Publication date: January $31^{\text {st }} 2021$

\section{Introduction}

Today, education is a very important part that cannot be separated from national development. This is because the development of education is one of the efforts to increase human resources, which is one of the main requirements to create a just and prosperous society. Development in the field of education has an important role in improving the quality of Indonesian human resources, namely Indonesian people who believe and have faith in God Almighty, have noble character, are independent, advanced, intelligent, creative, skilled, responsible and productive and are physically and mentally healthy.

In this global era, there are many unexpected challenges and threats, the demands of students in this era bring about various changes and dynamics. Students are part of the academic community in higher education that cannot be separated from activities that are routine in nature. Students as the younger generation are expected to be able to become agents of change and social control towards the environment and their regions and countries. Students who are part of the academic community in higher education are intellectuals who are not only capable of academics but also critical thinking and insight to answer problems that occur in every part of this country. Higher education institutions have the option of enhancing student creativity by naturally integrating it with the standard curriculum or teaching it alongside the standard curriculum. Therefore, it is necessary to have a university policy in developing activities to increase student creativity at Medan State University. The form of policy undertaken is to develop a model of activities or activities in the field of student affairs in the form of policy research titled "Development of Model Activities in Student Affairs"

\section{Statemen of the Problem}

This study seeks to find a model of student activity in higher education. Based on the model found, it is easier for universities to manage and carry out activities in the field of student affairs. The problems formulated in the research are problems of which the answers must be immediately sought out. 
2.1 Research Questions

1) What is the model of student affairs activities?

2) Is the student activity model that is being developed suitable for use?

3) Is the model of student affairs activities developed effectively used?2.2 Research Objectives

1) To find out the model of student activities

2) To find the feasibility of the developed student activity model

3) To find the effectiveness of the developed student affairs activity model

\section{Review of Related Literature}

\subsection{Activity and Creativity}

Activities in the field of student affairs are all carried out in the process of interaction in order to achieve goals. Activities in the field of student affairs are emphasized on students, because with student activities, an active situation is created. Student activities in various fields are more directed at generating creativity. This activity is carried out in accordance with those carried out by the ministry which are mostly dominated by creativity activities. For example, Student Science Week, Robot Contest, Entrepreneurship, Unmanned Ship Competition and so on which really need student creativity. In Kamus Besar Bahasa Indonesia (2005: 599), Creativity is the ability to create or inventiveness (KBBI, 1990: 456), creativity can also be meant as the latest and original creations created, because creativity is a unique mental process for produce something new, different and original. Creativity is an organized, comprehensive, imaginative brain activity leading to an original result. According to Amabile Theresa M (2012), "Creativity is the production of a novel and appropriate response, product, or solution to an open-ended task" (creativity is a process of something new, interesting, response, result or solution of a problem (open-ended).

Supriadi in Yeni Rachmawati (2005: 15) states that creativity is a person's ability to produce something new, either in the form of ideas or real works that are relatively different from what already exists. Creativity is a higherorder thinking ability that implies an escalation in thinking skills, marked by succession, discontinuity, differentiation, and integration between developmental stages. The definition of creativity which represents the conceptual definition and conceptual definition put forward by Stein (1967) is "the creative work is a novel work that is accepted as tenable or useful or satisfying by a group in some point in time". The dimensions of creativity according to this definition are reflected in the creativity criteria, namely novel, tenable, useful, and satisfying. On the other hand, the consensual dimension is expressed through the words that is accepted by a group in some point in time. Meanwhile, according to Clarkl Monstakis in Munandar (1995: 15), creativity is an experience in expressing and actualizing an individual's identity in an integrated form between the relationship between oneself, nature and others.

Slameto in Supriadi (2001: 17) says that the characteristics of creativity can be grouped into two categories, cognitive and non-cognitive. Cognitive characteristics include originality, flexibility, fluency, and elaboration. Meanwhile, non-cognitive characteristics include attitude motivation and creative creative personality. These two characteristics are equally important, intelligence that is not supported by a creative personality will not produce anything. Creativity can only be born from intelligent people who have a healthy psychological condition. Based on some of the definitions above, we can conclude that creativity is an individual mental process that generates effective new ideas, processes, methods or products that are imaginative, flexible, succession, and discontinuity. efficient in various fields for solving a problem. So creativity is part of one's business. Creativity will become art when someone carries out activities.

\subsection{Creativity Criteria}

The determination of creativity involves three dimensions, namely: the dimensions of the process, the person and the creative product. The creative process is the criterion for creativity, so all products resulting from the creative process are considered creative products, and the person is called a creator. The person dimension as a criterion for creativity is identical with the creative personality. Creative personality according to Guilford in Dedi Supriadi (2001: 13) includes cognitive and non-cognitive (interests, attitudes, temperamental qualities). Creative people have personality traits that are significantly different from non-creative people. These personality characteristics become the criteria for identifying creative people. Creative product, which refers to the results of one's actions, performance, or work in the form of goods or ideas This criterion is the most explicit in determining a person's creativity, so it is called the ultimate criterion for creativity.

Guilford (in Supriadi, 2001: 7) with his factor analysis found five characteristics that characterize the ability to think creatively, namely:

1) Fluency is the ability to produce multiple ideas.

2) Flexibility (flexibility) is the ability to propose various approaches and / or ways of solving a problem.

3) Originality (originality) is the ability to produce original ideas as a result of one's own thoughts and not clichés.

4) Elaboration is the ability to describe something in detail.

5) Redefinition is the ability to review / revisit a problem through a different way and perspective from what is 
customary.

\section{Methodology}

This research is a Developmental Research. The product of this research is the formation of a student activity model that can increase the creativity of students at the State University of Medan. The subjects of this study were students at the State University of Medan. There are 12 Student Activity Units and 1 Student Senate at the University level. In addition, there are 7 faculty level Student Senates and 7 Faculty Student Representative Bodies totaling 311 people. The sample used as research subjects were 100 people with the random sampling technique. This development research aimed to develop an activity model that can increase the creativity of Unimed students. The research method used was descriptive quantitative to see the implementation of program indicators, student responses, and changes to increase student reasoning and creativity. According to Borg and Gall (1983: 772), "educational research and development $(\mathrm{R} \& \mathrm{D})$ is a process used to develop and validate educational production" based on these quotes, research and development is carried out cyclically and at each step to be carried out refers to previous results to produce a new program.

Borg and Gall (1983: 775) proposed a series of stages that must be taken in this approach, namely "research and information collecting, planning, developing preliminary forms of product, preliminary field testing, main product revision, main field testing, operational product revision, operational field testing, final product revision, and dissemination and implementation ". Conceptually, the research and development approach to be carried out in this study includes these 10 general steps. The design of the activities for the development process of the reasoning and creativity improvement program to be carried out is presented in the following scheme

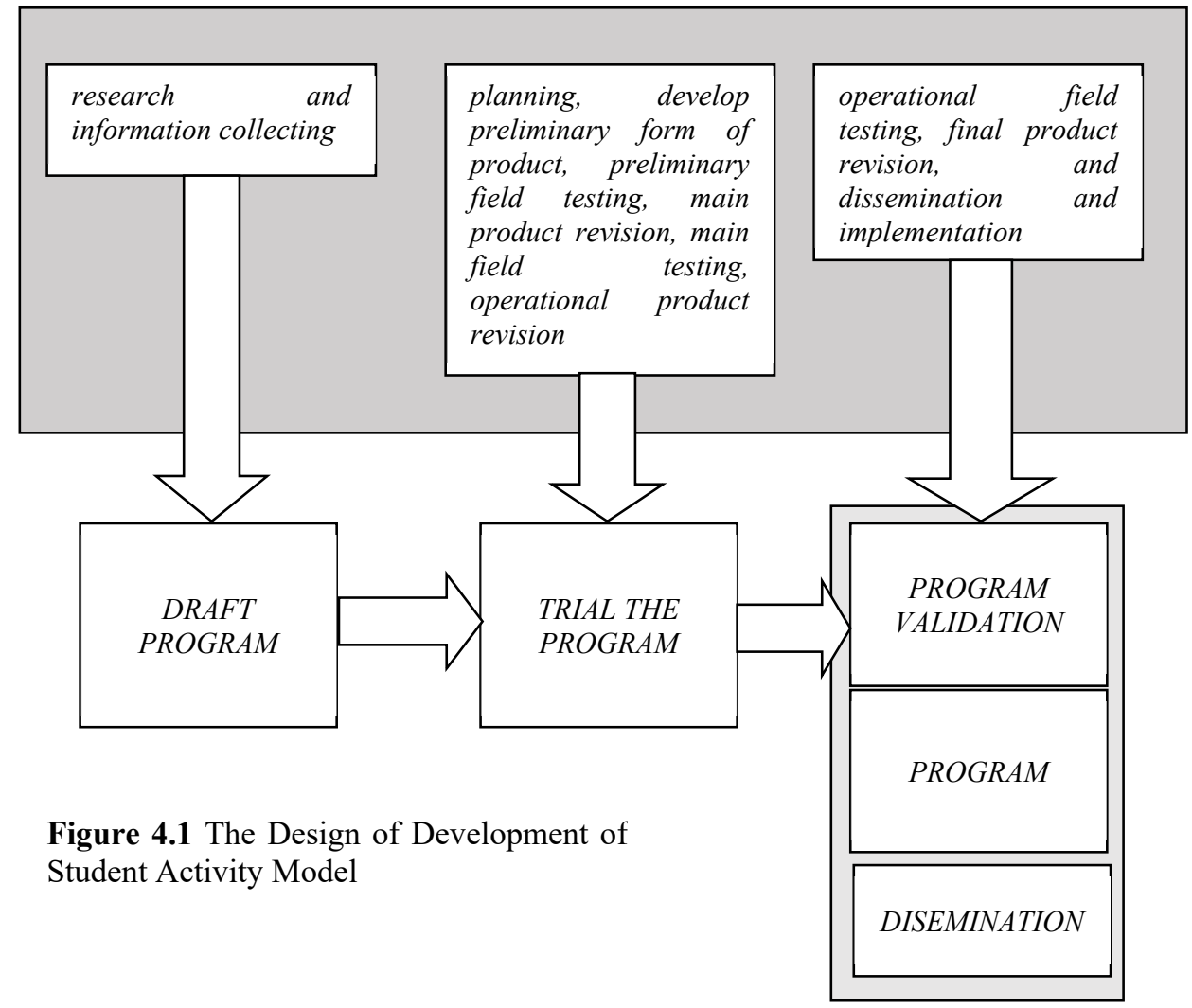

Collecting data in this study used instruments that will be compiled and developed, namely questionnaires, attitude assessment, observation guidelines, and interview guidelines. Prior to data collection, the initial activity carried out was validating all research instruments. Questionnaires were used to collect information or data from students at the survey stage to collect information about what has been and is currently being carried out. In addition, it was also used to collect information from students at the validation stage to determine possible adaptations and dissemination of programs that have been developed. Measuring the activity for each student involved in the student organization was a necessary step to find the level of creativity. Measurement of creativity was carried out through research instruments. Student activity observation guidelines were used to collect data at the limited trial stage and the wider trial. Interview guidelines were used at an early stage to explore or complete 
data and information from students regarding current conditions of reasoning and creativity. Interviews were also used at the program validation stage to determine the responses of the State University of Medan community regarding the possibility of adapting the developed program.

\section{Results}

Student activities at the State University of Medan are carried out based on a pattern of student development with reference to aspects of interests, talents, hobbies, and welfare. Student activities carried out both on and off campus must be approved by the university leadership, in this case represented by the Vice Chancellor for Student Affairs. In order for activities to run well, it is necessary to have operational standards for student activities that will be used as a reference for activities. These references can be used to regulate activities in such a way that what targets are aimed at can be obtained optimally.

Literature studies were conducted to obtain as much information as possible on research studies conducted. This activity involved several activities including reading several journals related to student activities. Besides, it also makes comparisons against several studies and rules made by several universities. Furthermore, this activity also saw references to several books that became references to develop student activities. From the results of this literature study, several research supporting instruments were developed including questionnaires, interviews, and observations. Mapping began by examining fields related to student affairs. Student Development Patterns consist of Reasoning and Knowledge, Talents and Interests, Spiritual Welfare and Scholarships, Social Care, and Supporting Activities. One new field that is starting to get busy in students is entrepreneurship. This field can be included in various student activities, for example reasoning and scholarship, talents and interests and so on. Activities related to reasoning and science are Indonesian National Student Scientific Week. National University Debate Competition, Indonesian Student Debate Competition. Those related to talents and interests include National Sports, National Art Competition, International Choir. Student activities related to welfare include Musabaqah Tilawatil Quran, Chucrh Song Competitio, Crishmast Celeberation, Maulid. While activities related to community development is Holistic Village Development and Empowerment Program, a community service event for the Unimed Student Senate in Dareah Langkat. Supporting activities are Ormawa Character Development, New Student Character Development, Implementing Traineeng of Trainer for Student Creatifity Program Supervisors. Based on the type and process of implementing activities, to achieve the desired activity targets, the student activity model used is as follows:National

In the diagram, the Student Activity Activity Model is as follows:

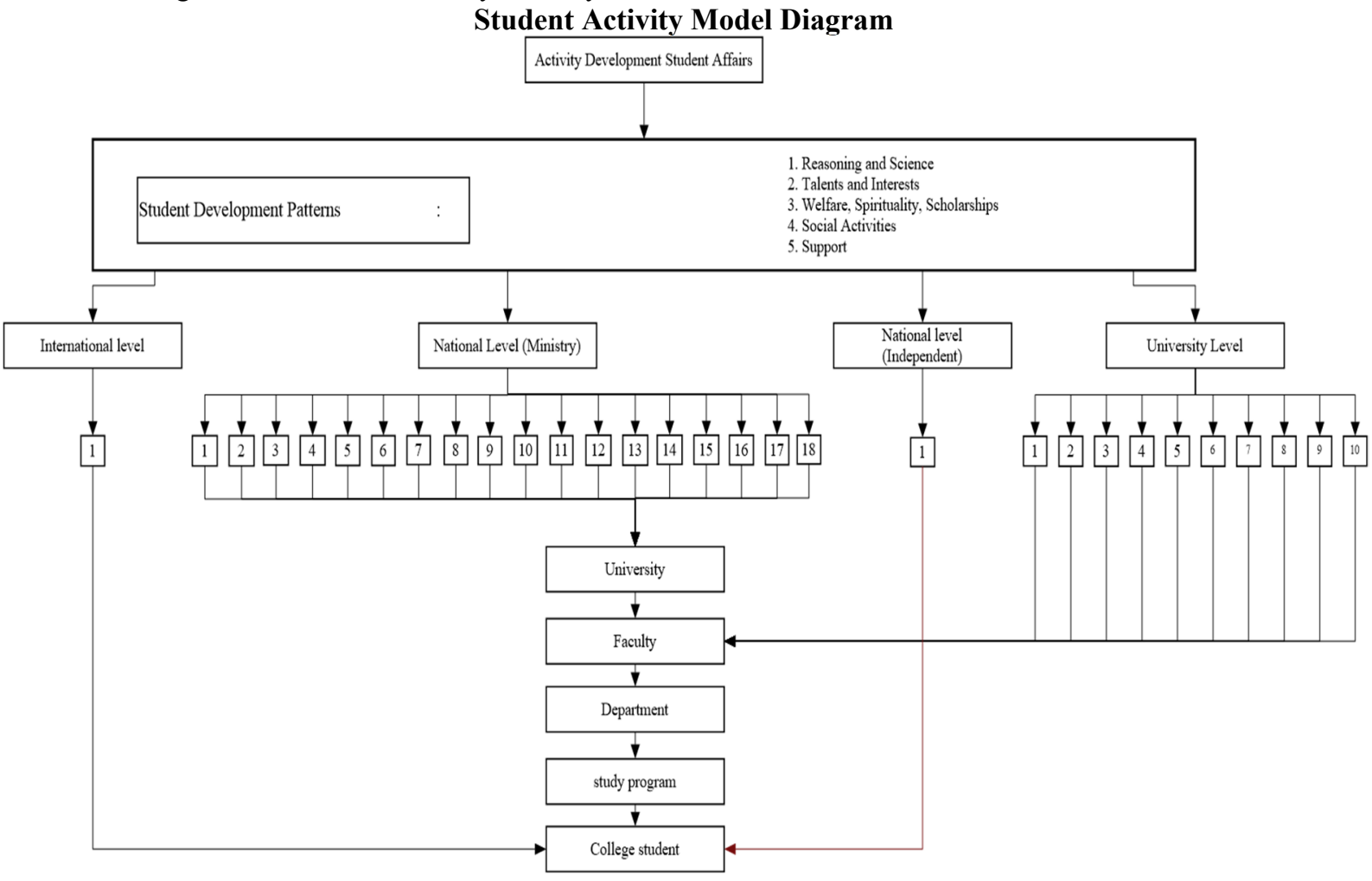

Description of the Student Activity Model Diagram:

In general, student activities participate in activities / competitions at various levels, including: 


\section{International}

1. Indonesia Malaysia Thailand - Growth Triangle Varsity Carnival

National Activities organized by the Ministry

1. National Student Scientific Week

2. National Student Sports Week

3. Musabaqah Tillawatil Qur'an

4. Ecclesiastical Choir Party Students

5. National Student Art Week

6. National University debating Championship

7. Indonesian Student Debate Competition

8. Student Achievement Selection

9. National Mathematics and Natural Sciences Competition

10. Indonesian Student Business Competition

11. Holistic Village Development and Empowerment Program

12. Student Digital Innovation Competition

13. Student Business Innovation Competition

14. Indonesian Robot Contest

15. National Unmanned Fast Boat Contest

16. Indonesian Student Entrepreneurial Assistance

17. EXPO-Indonesian Student Entrepreneurialship

18. National Student Performance in Information and Communication Technology

National Activities held independently by the campus

1. National Entrepreneurship Student Program Workshop

\section{University level}

1. Character Education Development for Students Organizations

2. Practice management skills of students

3. Anti-Narcotics Socialization on Campus

4. Student Senate Election

5. Student Creative Program Workshop

6. Student Creative Program Training of Traine

7. Student Creative Program Technical Guidance

8. Student Creative Program Lecturer Assistance

9. Entrepreneurial Student Program Socialization

10. Religious activity

Based on the research instrument used, the following results were obtained:

Table 1. Student Attitudes Toward Patterns of Student Activity Development at The State University of Medan

\begin{tabular}{|l|l|l|l|l|l|l|l|}
\hline \multirow{2}{*}{ No. } & Name of activity & \multicolumn{3}{l|}{ Student Statement } & \multirow{2}{*}{ Average } & Category \\
\cline { 3 - 7 } & & Very good & Good & Moderately good & Not good & & \\
\hline 1 & Reasoning and Science & 84 & 14 & 2 & - & 3.8 & Very good \\
\hline 2 & Talents and Interests & 86 & 10 & 3 & 1 & 3.8 & Very good \\
\hline 3 & Welfare, Spirituality, Scholarships & 85 & 12 & 2 & 1 & 3.8 & Very good \\
\hline 4 & Social Activities & 83 & 11 & 5 & 1 & 3,7 & Very good \\
\hline 5 & Support & 82 & 10 & 6 & 2 & 3,7 & Very good \\
\hline
\end{tabular}

Student responses to various student coaching activities in Table 1 indicate that: in the activities of reasoning, talents and interests, welfare shows a very good category. These results indicate that the activities of student coaching patterns at Unimed attract overall student interest. 
Table 2. Students' Attitudes Toward the Process of Implementing Reasoning and Scientific Activities

\begin{tabular}{|c|c|c|c|c|c|c|c|}
\hline \multirow{2}{*}{ No. } & \multirow{2}{*}{ Name of activity } & \multicolumn{4}{|c|}{ Student Statement } & \multirow{2}{*}{ Average } & \multirow{2}{*}{ Category } \\
\hline & & $\begin{array}{l}\text { Very } \\
\text { good }\end{array}$ & Good & $\begin{array}{l}\text { Moderately } \\
\text { good }\end{array}$ & $\begin{array}{l}\text { Not } \\
\text { good }\end{array}$ & & \\
\hline 1 & REASON AND SCIENCE & & & & & & \\
\hline 1.1 & National Student Scientific Week & 90 & 8 & 2 & - & 3,9 & $\begin{array}{l}\text { Very } \\
\text { good }\end{array}$ \\
\hline 1.2 & $\begin{array}{l}\text { National University Debating } \\
\text { Competition }\end{array}$ & 88 & 10 & 2 & - & 3.8 & $\begin{array}{l}\text { Very } \\
\text { good }\end{array}$ \\
\hline 1.3 & $\begin{array}{l}\text { Indonesian Student Debate } \\
\text { Championship }\end{array}$ & 84 & 14 & 2 & - & 3.8 & $\begin{array}{l}\text { Very } \\
\text { good }\end{array}$ \\
\hline 1.4 & Student Achievement Selection & 80 & 10 & 8 & 2 & 3,7 & $\begin{array}{l}\text { Very } \\
\text { good }\end{array}$ \\
\hline 1.5 & $\begin{array}{l}\text { National Mathematics and Natural } \\
\text { Sciences Competition }\end{array}$ & 80 & 5 & 10 & 5 & 3,6 & $\begin{array}{l}\text { Very } \\
\text { good }\end{array}$ \\
\hline 1.6 & $\begin{array}{lll}\text { Indonesian } & \text { Student } & \text { Business } \\
\text { Competition } & & \\
\end{array}$ & 78 & 10 & 10 & 2 & 3,6 & $\begin{array}{l}\text { Very } \\
\text { good }\end{array}$ \\
\hline 1.7 & $\begin{array}{l}\text { Student Business Innovation } \\
\text { Competition }\end{array}$ & 76 & 12 & 11 & 1 & 3,6 & $\begin{array}{l}\text { Very } \\
\text { good }\end{array}$ \\
\hline 1.8 & $\begin{array}{l}\text { Holistic Village Development and } \\
\text { Empowerment Program }\end{array}$ & 70 & 20 & 9 & 1 & 3,4 & Good \\
\hline 1.9 & $\begin{array}{l}\text { Indonesian Student } \\
\text { Entrepreneurial Assistance }\end{array}$ & 75 & 20 & 4 & 1 & 3,7 & $\begin{array}{l}\text { Very } \\
\text { good }\end{array}$ \\
\hline 1.10 & $\begin{array}{ll}\text { EXPO-Indonesian } & \text { Student } \\
\text { Entrepreneurialship } & \\
\end{array}$ & 82 & 10 & 7 & 1 & 3,7 & $\begin{array}{l}\text { Very } \\
\text { good }\end{array}$ \\
\hline 1.11 & $\begin{array}{l}\text { National Student Performance in } \\
\text { Information and Communication } \\
\text { Technology }\end{array}$ & 70 & 18 & 8 & 4 & 3.5 & Good \\
\hline
\end{tabular}

Table 3. Student Attitudes Toward the Process of Implementing Talent and Interests Activities

\begin{tabular}{|l|l|l|l|l|l|l|l|}
\hline \multirow{2}{*}{$\begin{array}{l}\text { No } \\
\text { N }\end{array}$} & \multirow{2}{*}{ Name of activity } & \multicolumn{2}{|l|}{ Student Statement } & \multirow{2}{*}{ Average } & Category \\
\cline { 3 - 8 } & $\begin{array}{l}\text { Very } \\
\text { good }\end{array}$ & Good & $\begin{array}{l}\text { Moderately } \\
\text { good }\end{array}$ & Not good & \\
\hline 2 & TALENT AND INTEREST & & & & & & \\
\hline 2.1 & $\begin{array}{l}\text { National Student Sports } \\
\text { Week }\end{array}$ & 90 & 6 & 3 & 1 & 3.8 & Very good \\
\hline 2.2 & National Student Art Week & 90 & 7 & 1 & - & 3.8 & Very good \\
\hline 2.3 & $\begin{array}{l}\text { Practice management skills } \\
\text { of students }\end{array}$ & 84 & 10 & 5 & 1 & 3,7 & Very good \\
\hline
\end{tabular}

Table 4. Student Attitudes Toward the Process of Implementing Welfare and Spiritual Activities

\begin{tabular}{|c|c|c|c|c|c|c|c|}
\hline \multirow{2}{*}{$\begin{array}{l}\text { No } \\
\text {. }\end{array}$} & \multirow{2}{*}{ Name of activity } & \multicolumn{4}{|c|}{ Student Statement } & \multirow{2}{*}{ Average } & \multirow{2}{*}{ Category } \\
\hline & & $\begin{array}{l}\text { Very } \\
\text { good }\end{array}$ & Good & $\begin{array}{l}\text { Moderately } \\
\text { Good }\end{array}$ & Not good & & \\
\hline 3 & WELFARE, FOUNDATION & & & & & & \\
\hline 3.1 & Musabaqah Tillawatil Qur'an & 91 & 8 & 1 & - & 3,9 & Very good \\
\hline 3.2 & $\begin{array}{l}\text { Ecclesiastical Choir Party } \\
\text { Students }\end{array}$ & 90 & 8 & 2 & - & 3,9 & Very good \\
\hline 3.3 & Maulid Celebration & 91 & 7 & 1 & 1 & 3,9 & Very good \\
\hline 3.4 & Christmast Celeberation & 91 & 8 & 1 & - & 3,9 & Very good \\
\hline
\end{tabular}


Table 5. Student Attitudes Toward the Implementation Process of Social Care Activities

\begin{tabular}{|l|l|l|l|l|l|l|l|}
\hline \multirow{2}{*}{ No. } & \multirow{2}{*}{ Name of activity } & \multicolumn{2}{|l|}{ Student Statement } & \multirow{2}{*}{ Average } & Category \\
\cline { 3 - 8 } & $\begin{array}{l}\text { Very } \\
\text { good }\end{array}$ & Good & $\begin{array}{l}\text { Moderately } \\
\text { good }\end{array}$ & $\begin{array}{l}\text { Not } \\
\text { good }\end{array}$ & \\
\hline 4 & COMMUNITY SERVICE & & & & & & \\
\hline 4.1 & $\begin{array}{l}\text { Holistic Village Development } \\
\text { and Empowerment Program }\end{array}$ & 76 & 10 & 11 & 3 & 3,6 & Very good \\
\hline 4.2 & $\begin{array}{l}\text { Community Service for the } \\
\text { Student Senate of Medan State } \\
\text { University }\end{array}$ & 75 & 15 & 8 & 2 & 3,6 & Very good \\
\hline
\end{tabular}

Table 6. Student Attitudes Toward the Implementation Process of Supporting Activities

\begin{tabular}{|c|c|c|c|c|c|c|c|}
\hline \multirow{2}{*}{ No. } & \multirow{2}{*}{ Name of activity } & \multicolumn{4}{|c|}{ Student Statement } & \multirow{2}{*}{ Average } & \multirow{2}{*}{ Category } \\
\hline & & $\begin{array}{l}\text { Very } \\
\text { good }\end{array}$ & Good & $\begin{array}{l}\text { Moderately } \\
\text { good }\end{array}$ & $\begin{array}{l}\text { Not } \\
\text { good }\end{array}$ & & \\
\hline 5 & SUPPORT & & & & & & \\
\hline 5.1 & $\begin{array}{l}\text { Character Education } \\
\text { Development for Student } \\
\text { Organization Managers }\end{array}$ & 94 & 4 & 2 & - & 3,9 & Very good \\
\hline 5.2 & Anti Drug Socialization & 93 & 5 & 2 & - & 3,9 & Very good \\
\hline 5.3 & $\begin{array}{l}\text { Student Creative Program } \\
\text { Lecturer Assistance }\end{array}$ & 96 & 3 & 1 & - & 3,9 & Very good \\
\hline
\end{tabular}

Table 7. Students' Attitudes Toward Supporting Activities Implementation Process

\begin{tabular}{|c|c|c|c|c|c|c|c|}
\hline \multirow{2}{*}{ No. } & \multirow{2}{*}{ Name of activity } & \multicolumn{4}{|c|}{ Student Statement } & \multirow{2}{*}{ Average } & \multirow{2}{*}{ Category } \\
\hline & & $\begin{array}{l}\text { Very } \\
\text { good }\end{array}$ & Good & $\begin{array}{l}\text { Moderately } \\
\text { good }\end{array}$ & Not good & & \\
\hline 6 & $\begin{array}{l}\text { INTERNATIONAL } \\
\text { EVEN }\end{array}$ & & & & & & \\
\hline 6.1 & $\begin{array}{l}\text { Indonesia Malaysia } \\
\text { Thailand - Growth } \\
\text { Triangle) Varsity Carnival }\end{array}$ & 96 & 3 & 1 & - & 3,9 & Very good \\
\hline 6.2 & International Choir & 92 & 7 & 1 & - & 3,9 & Very good \\
\hline
\end{tabular}

Table 8. Students' Attitudes Toward the Implementation Process of Independent National Activities

\begin{tabular}{|c|c|c|c|c|c|c|c|}
\hline \multirow{2}{*}{ No. } & \multirow{2}{*}{ Name of activity } & \multicolumn{4}{|c|}{ Student Statement } & \multirow{2}{*}{ Average } & \multirow{2}{*}{ Category } \\
\cline { 3 - 7 } & & Very good & Good & $\begin{array}{c}\text { Moderately } \\
\text { good }\end{array}$ & $\begin{array}{c}\text { Not } \\
\text { good }\end{array}$ & & \\
\hline 7 & $\begin{array}{c}\text { MANDIRI NATIONAL } \\
\text { ACTIVITIES }\end{array}$ & & & & & & \\
\hline 7.1 & Business Plan Competition & 91 & 8 & 1 & - & 3,9 & $\begin{array}{c}\text { Very } \\
\text { good }\end{array}$ \\
\hline
\end{tabular}

The table above shows, that the implementation process of coaching in the field of student affairs at the State University of Medan is going very well, this is evident from the answers to the student attitudes being in the very good category. Based on students' attitudes towards student development patterns and the process of implementing student activities, it can be concluded that all student activities at the State University of medan attract student interest and are feasible to use. 
Table 9: Student Satisfaction Level of Development Patterns and Implementation Process Unimed Student Activities

\begin{tabular}{|c|c|c|c|c|c|}
\hline No. & Aspect & $\begin{array}{l}\text { Not } \\
\text { satisfied }\end{array}$ & $\begin{array}{l}\text { Less } \\
\text { satisfied }\end{array}$ & Satisfied & $\begin{array}{l}\text { Very } \\
\text { satisfied }\end{array}$ \\
\hline \multicolumn{6}{|c|}{ Reasoning and Science } \\
\hline 1 & $\begin{array}{l}\text { Availability of services to students to develop } \\
\text { reasoning (academic field) }\end{array}$ & $10 \%$ & $15 \%$ & $70 \%$ & $5 \%$ \\
\hline 2 & $\begin{array}{l}\text { Availability of Student Activity Units (UKM) to } \\
\text { develop reasoning and scholarship }\end{array}$ & $2 \%$ & $2 \%$ & $80 \%$ & $16 \%$ \\
\hline 3 & $\begin{array}{l}\text { Availability of service quality by academic } \\
\text { supervisors in developing reasoning and scholarship }\end{array}$ & $5 \%$ & $5 \%$ & $80 \%$ & $10 \%$ \\
\hline 4 & $\begin{array}{l}\text { Availability of activities in the form of training / } \\
\text { workshops / seminars to support / guide student } \\
\text { careers }\end{array}$ & $10 \%$ & $20 \%$ & $69 \%$ & $1 \%$ \\
\hline 5 & $\begin{array}{l}\text { The availability of facilities that support the } \\
\text { implementation of student reasoning and scientific } \\
\text { development }\end{array}$ & $10 \%$ & $10 \%$ & $75 \%$ & $5 \%$ \\
\hline \multicolumn{6}{|c|}{ Interest and talent } \\
\hline 1 & $\begin{array}{l}\text { Availability of regular outreach on Arts and Sports } \\
\text { coaching }\end{array}$ & $5 \%$ & $5 \%$ & $75 \%$ & $15 \%$ \\
\hline 2 & $\begin{array}{l}\text { The availability of services to foster students' talents } \\
\text { and interests }\end{array}$ & $5 \%$ & $5 \%$ & $80 \%$ & $10 \%$ \\
\hline 3 & $\begin{array}{l}\text { The availability of service units (UKM) to foster } \\
\text { talents and interests of students }\end{array}$ & $5 \%$ & $5 \%$ & $80 \%$ & $10 \%$ \\
\hline 4 & $\begin{array}{l}\text { The implementation of various trainings for } \\
\text { developing student talents and interests }\end{array}$ & $10 \%$ & $15 \%$ & $73 \%$ & $2 \%$ \\
\hline 5 & $\begin{array}{l}\text { The availability of facilities and infrastructure for } \\
\text { developing talents and interests }\end{array}$ & $10 \%$ & $5 \%$ & $80 \%$ & $5 \%$ \\
\hline \multicolumn{6}{|c|}{ Social Care } \\
\hline 1 & Availability of community service facilities & $5 \%$ & $3 \%$ & $80 \%$ & $12 \%$ \\
\hline 2 & $\begin{array}{l}\text { Availability of Student Activity Implementation } \\
\text { Programs to the community }\end{array}$ & $1 \%$ & $2 \%$ & $88 \%$ & $9 \%$ \\
\hline 3 & Availability of health service facilities for students & $7 \%$ & $9 \%$ & $78 \%$ & $6 \%$ \\
\hline 4 & $\begin{array}{l}\text { Availability of Guidance for Students by Lecturers as } \\
\text { Supervisors }\end{array}$ & $6 \%$ & $10 \%$ & $80 \%$ & $4 \%$ \\
\hline 5 & $\begin{array}{l}\text { Availability of facilities and infrastructure in } \\
\text { carrying out community service }\end{array}$ & $5 \%$ & $5 \%$ & $80 \%$ & $10 \%$ \\
\hline \multicolumn{6}{|c|}{ Social welfare } \\
\hline 1 & $\begin{array}{l}\text { Availability of guidance services for students to } \\
\text { carry out religious activities }\end{array}$ & $10 \%$ & $15 \%$ & $70 \%$ & $5 \%$ \\
\hline 2 & $\begin{array}{l}\text { Availability of Student Activity Units (UKM) to } \\
\text { carry out religious activities }\end{array}$ & $2 \%$ & $2 \%$ & $80 \%$ & $16 \%$ \\
\hline 3 & $\begin{array}{l}\text { The availability of facilities for students to carry out } \\
\text { religious activities }\end{array}$ & $5 \%$ & $5 \%$ & $80 \%$ & $10 \%$ \\
\hline 4 & $\begin{array}{l}\text { Availability of activities in the form of training / } \\
\text { workshops / seminars to support / guide student } \\
\text { religious activities }\end{array}$ & $10 \%$ & $20 \%$ & $69 \%$ & $1 \%$ \\
\hline 5 & $\begin{array}{l}\text { The availability of information, services and } \\
\text { scholarships for students }\end{array}$ & $10 \%$ & $10 \%$ & $75 \%$ & $5 \%$ \\
\hline \multicolumn{6}{|c|}{ Career and Entrepreneurship Guidance } \\
\hline 1 & $\begin{array}{l}\text { Availability of regular outreach on career guidance } \\
\text { by academic supervisors }\end{array}$ & $10 \%$ & $5 \%$ & $80 \%$ & $5 \%$ \\
\hline 2 & Availability of career guidance services & $10 \%$ & $10 \%$ & $75 \%$ & $5 \%$ \\
\hline 3 & $\begin{array}{l}\text { The implementation of various Entrepreneurship } \\
\text { trainings on a regular basis }\end{array}$ & $5 \%$ & $10 \%$ & $80 \%$ & $5 \%$ \\
\hline
\end{tabular}




\begin{tabular}{|l|l|l|l|l|l|}
\hline No. & Aspect & $\begin{array}{l}\text { Not } \\
\text { satisfied }\end{array}$ & $\begin{array}{l}\text { Less } \\
\text { satisfied }\end{array}$ & Satisfied & $\begin{array}{l}\text { Very } \\
\text { satisfied }\end{array}$ \\
\hline 4 & $\begin{array}{l}\text { The availability of a forum to facilitate student } \\
\text { entrepreneurship }\end{array}$ & $10 \%$ & $15 \%$ & $70 \%$ & $5 \%$ \\
\hline 5 & Availability of various entrepreneurial activities & $10 \%$ & $10 \%$ & $75 \%$ & $5 \%$ \\
\hline Supporting Activities & $\begin{array}{l}\text { The availability of socialization about character for } \\
\text { students }\end{array}$ & $10 \%$ & $75 \%$ & $5 \%$ \\
\hline 1 & $\begin{array}{l}\text { The availability of activities and outreach on Drug } \\
\text { Prevention Strategies for students }\end{array}$ & $1 \%$ & $2 \%$ & $88 \%$ & $9 \%$ \\
\hline 3 & $\begin{array}{l}\text { The availability of activities and socialization on the } \\
\text { Prevention Strategy of sexuality for the Unimed } \\
\text { academic community }\end{array}$ & $7 \%$ & $9 \%$ & $78 \%$ & $6 \%$ \\
\hline 4 & $\begin{array}{l}\text { Availability of Management Skills Training } \\
\text { Activities for Students }\end{array}$ & $5 \%$ & $10 \%$ & $80 \%$ & $5 \%$ \\
\hline 5 & $\begin{array}{l}\text { Availability of Socialization on Character Education } \\
\text { for Ormawa. }\end{array}$ & $5 \%$ & $5 \%$ & $85 \%$ & $5 \%$ \\
\hline
\end{tabular}

Based on students' attitudes towards student activity patterns, student activity processes and the level of student satisfaction with student activities at the State University of Medan, it can be concluded that the Student Activity Development Model offered in this study is effective to use.

\section{Discussion}

The results showed that the majority of students show positive attitutdes towards various student coaching activities (reasoning activities 100 people, talents and interests 86 people, welfare 85 people, social activities 83 people). These results indicate that the activities of student coaching patterns at the State University of Medan attract overall student interest. The process of implementing student affairs coaching at the university went very well. This was evident from the answers to the attitude of students being in the very good category. TYhe level of student satisfaction with all student activities at the State University of Medan shows that students are satisfied. Based on students' attitudes towards student development patterns and the process of implementing student activities, it can be concluded that all student activities at Unimed attract student interest and are feasible to use. Based on the students' attitudes towards the student activity process and the level of student satisfaction with student activities, it can be concluded that the Student Activity Development Model offered in this study is effective to use.

\section{Conclusion and Recommendations}

The purpose of this study is to produce a model of student activity in the field of student affairs at the State University of Medan, the feasibility of the model being developed and whether the model is effective or not. The results indicate that the activity model developed is feasible and effective to use. Based on this finding, the following are recommended:

1. Student activity model based on Student Development Patterns is relatod to reasoning and knowledge, talents and interests, social and spiritual welfare, social activities, supporting activities

2. The model developed based on the Student Development Pattern at Unimed is feasible to use

3. The model developed based on the Student Development Pattern at Unimed is effectively used to improve student achievement

\section{Reference}

Baroody, AJ, (2009). Problem Solving, Reasoning and Communication, k-8 Helping Children Think Mathematically. New York. Macmillar Publishing Company

Borg, WR and Gall, MD (1983). Educational research An Introduction. New York: Longman.

Director of Research and Community Service Kemenristekdikti. 2015. Guidelines for Student Creativity Program.

Distance Learning.Retrieved December 15, 20016 from http://www.irrodl.org/content/v5.2/rovai-jordan.html, p13. Schreiner, E. (2010). 10 Ways to improve blended learning course design.

Kanimozhi, P., Ganesan, P. Reasoning Ability Among Higher Secondary Students. International Journal Of Research Granthaalayah

Kose, U. (2010). A blended learning model supported with Web 2.0 technologies. Procedia and Social and Behavioral Sciences, 2, 2794-2802.

Lickona, Tom; Schaps, Eric, \& Lewis, Catgerine. 1998. "Eleven Principles of Effective Character Education” In Scholastic Early Childhood Today, Nov / Dec 1998., 13; 3; . ProQuest Eduation Journals page 53-55./. 
Melinda, CB., Berkowitz MW. (2005). What Work in Character Education? Leadership For Students Activities, October 2005, vol 34, no 2, pages 1-7. EDUCATION: Jakarta, September 2005.

Rosyadi Slamnet. 2018 Industrial Revolution 4.0: Opportunities and Challenges for Open University Alumni. Papers. Delivered in February 2018

Rovai, AP and Jordan, HM (2004). Blended learning and sense of community: A comparative analysis with traditional and fully online graduate courses. International Review of Research in Open and

Schwartz, AJ. (2000). It's Not to Late to Teach College Student about Values. The Chronicle of Higher Education. Vol 46. No 40.pg A68 Siswanto, HW. (2011).

Stiff-William, HR. (2010). Widening Lens to Teach Character Education Alongside Standard Curriculum. Abstract. The Clearing House. Vol 83.no 4.pg 115-120. www.neraca.co.id. The lowest quality of Indonesian human resources in ASEAN. November 6, 2011, downloaded April 12, 2016.

Thank God. (2009). The Role of Education in Higher Education towards Changes in the Behavior of Intellectuals (Social-Individual). Creative Scientific Journal, vol 6 no 1, pp. 1-15. 